\title{
NOTES
}

\section{FEDERAL CIVIL PROCEDURE: FOURTH CIRCUIT ADOPTS "SPECIAL CIRCUMSTANCES" AS "GOOD CAUSE" TEST FOR RULE 34}

Rute 34 of the Federal Rules of Civil Procedure permits the inspection of documents in the possession of an opposing party upon a showing of "good cause." The Court of Appeals for the Fourth Circuit recently held in Guilford National Bank v. Southern Ry. ${ }^{2}$ that "good cause" requires some specific showing of "special circumstances" before the inspection of witness statements will be allowed.

The discovery issue in Guilford arose out of a wrongful death action based on a crossing collision between a train and an automobile. Within six days after the accident, the defendant Southern Railway's claim agent obtained written statements from witnesses, including the train crew. The attorney for the plaintiff estate began to investigate by the sixth day. Although he interviewed some witnesses, he did not interview any of the train crew. In no instance did he take written statements. $^{3}$ A year later he attempted to obtain through rule 34 the written statements in Southern's possession. The trial court ordered the production of the statements on the grounds that they were "relevant" to the controversy, unique and irreplaceable by deposition, and in

\footnotetext{
${ }^{1}$ The rule provides: "Upon motion of any party showing good cause therefor and upon notice to all other parties, and subject to the provisions of Rule $30(\mathrm{~b})$, the court in which an action is pending may ( 1 ) order any party to produce and permit the inspection and copying or photographing, by or on behalf of the moving party, of any designated documents, papers, books, accounts, letters, photographs, objects, or tangible things, not privileged, which constitute or contain evidence relating to any of the matters within the scope of the examination permitted by Rule 26(b) and which are in his possession, custody, or control. ..."

Practical considerations, depending on the particular facts of each case, usually determine "good cause." See 4 MOORE, FEDERAL Practice I 34.08, at 2449-5I (2d ed. 1950) [hereinafter cited as MOORE]. Since the term "good cause" lacks a particular frame of reference, the judge really makes a "comparative evaluation of competing claims of need and prejudice." United Air Lines, Inc. v. United States, 26 F.R.D. 213, 217 (D. Del. 1960). But a court is under no duty to search out good cause; therefore, the motion should be accompanied by an affidavit setting forth facts that establish the need for inspection. 4 MOORE I 34.07, at 2442-43.

2297 F.2d 921 (4th Cir. 1962).

${ }^{8}$ Brief for Appellant, pp. A13-14.
} 
Southern's exclusive possession. ${ }^{4}$ Southern refused to comply and was held in contempt. ${ }^{5}$

The Court of Appeals reversed the contempt order, holding that "relevancy" was not equivalent to "good cause" and that the additional circumstances shown by the plaintiff were insufficient to justify the discovery order. ${ }^{6}$ According to the court, opportunities to obtain by deposition, interrogatories, or mutual exchange the "substance" of the information in Southern's statements apparently still existed. The court was also impressed by the past opportunities of the plaintiff's attorney to obtain written statements. ${ }^{7}$ It distinguished Guilford from

${ }_{24}$ F.R.D. 493 (M.D.N.C. 1960). The trial court also felt that Southern would not be materially prejudiced by making the disclosure because a North Carolina Middle District court rule required that the names of witnesses and the "nature of their testimony" had to be disclosed in advance of trial. Id. at 500. This rule provides that "attorneys for each of the parties shall furnish opposing counsel with the written list of the names and addresses of all witnesses then known, together with a brief statement of what counsel proposes to establish by the testimony of each witness ...." M.D.N.C.R. $22(\mathrm{~g})(4), 5$ FED. Rules SERv. 2d, Local Court Rules 727 (1962).

Furthermore, the trial judge believed that his decision was consistent with previous Fourth Circuit holdings in New York Cent. R.R. v. Carr, 25 I F.2d 433 (4th Cir. 1957) and Tiedman v. American Pigment Corp., 253 F.2d 803 (4th Cir. 1958). The Carr case affirmed an order to produce the plaintiff's own statement given to a claim agent shortly after an accident while the plaintiff was still hospitalized and unrepresented by counsel on the ground that it would only be fair to a "co-operative employee," whose memory has dimmed in the intervening months. In Tiedman the court affirmed the denial of a motion to inspect all books, records and correspondence pertaining to a contract claim because the plaintiff's ability to prepare his case had not been adversely affected and he had made no effort to show "good cause." Both of these cases are factually distinguishable from Guilford. In Tiedman, as in Guilford, however, it was the moving party who had to show that his ability to prepare his case would be unfairly prejudiced. Under some other discovery device, such as rule 26, the opposing party would have to show that the discovery of materials in his possession would be economically and prejudicially burdensome. In this sense, Guilford is no departure from Tiedman, although some of the language in Tiedman was not as liberal as it appeared to be.

"Since the contempt order was a "final" order, it could be appealed. See 4 MOORE I 26.37[3], at 1215 ; Developments in the Law-Discovery, 74 HARV. L. REv. 940, 996 (I $96 \mathrm{I}$ ) [hereinafter cited as Developments].

"In comparing rule 34 with the other discovery rules, the court stated that "there must be a greater showing of need under Rules 34 and 35 than under other discovery rules" and noted that the Supreme Court did not act on the recommendation of the Advisory Committee to delete "good cause" from rule 34. The court distinguished cases relied on by the district court that involved "indispensable" business records. Thus the court was "not prepared to depart from the explicit language of Rule 34 when viewed in the context of the entire discovery section." 297 F.2d at 923-25. Accord, Hauger v. Chicago, R.I. \& P.R.R., 216 F.2d 501 (7th Cir. 1954); McSparren v. Bethlehem-Cuba Iron Mines Co., 26 F.R.D. 6Ig (E.D. Pa. I960).

7 "Absent circumstances to the contrary, there is no reason to suppose that an 
similar cases in which the plaintiff had no actual opportunity to investigate until weeks or months after the accident. Implicit in the court's. holding was an attempt to encourage independent, diligent investigation by both parties ${ }^{8}$ and to discourage any unfair use of rule 34, a potentially "harassing" weapon. ${ }^{9}$

The Fourth Circuit's decision in Guilford embodied a generally accepted, but conservative, discovery-limiting attitude toward rule $34^{10}$ The trial court, on the other hand, took a more liberal attitude, striving to maximize pre-trial disclosure. ${ }^{11}$ Both courts were concerned, how-ever, with a basic "good cause" question: whether the desired information was available by some means other than actual inspection. ${ }^{12}$ The proper answer varies with the nature of the desired information, its importance to issues in the case, and the extent to which an independent

interview of a witness six days, or even nine days, after the accident is any less reliable than a statement taken on the day following the accident [referring to interviews with witnesses other than the train crew; see note 3 supra] .... The case might be different if the plaintiff had taken depositions of the employec-witnesses, or at least interviewed them. ..." 297 F.2d at 926 . For a similar reaction, see Wilson v. David, 21 F.R.D. 217 (W.D. Mich. 1957) (party represented by counsel within two days after accident had same ability to make complete investigation).

${ }^{8}$ "The plaintiff cannot be permitted to rely entirely upon the defendant's efforts .... . Discovery was hardly intended to enable a learned profession to perform its functions either without wits or on wits borrowed from the adversary [Hickman v. Taylor, 329 U.S. 495, $5 \times 6$ (1947) (Jackson, J., concurring)]. . . . [C]ounsel's natural desire to learn the details of his adversary's preparation for trial, to take advantage of his adyersary's industry in seeking out and interviewing prospective witnesses, to help prepare himself to examine witnesses or to make sure that he had overlooked nothing are certainly not such special circumstances .... [Alltmont v. United States, 177 F.2d 971, 978 (3d Cir. 1949)]." 297 F.2d at 926-27. But see Taine, Discovery of Trial Preparation in the Federal Courts, 50 CoLUM. L. Rev. 1026, 1038 (1950).

s![C]ompelling the production of documents under Rule 34 can be extremely harassing. Use of the weapons which this rule forges should not be permitted without more than the easily satisfied test of relevancy." 297 F.2d at 924. But see Frost, Ascertainment of Truth by Discovery, 28 F.R.D. 89, 93 (196I) (discovery tools described as "potent weapons in the arsenal of the attorney in search of truth").

${ }^{10}$ Accord, Hauger v. Chicago, R.I. \& P.R.R., 216 F.2d 501 (7th Cir. 1954); Williams v. Continental Oil Co., 215 F.2d 4 (1oth Cir. 1954); Alltmont v. United .States, ${ }_{77}$ F.2d 971 (3d Cir. 1949), cert. denied, 339 U.S. 967 (1950); Martin v. Capital Transit Co., r 70 F.2d 8 II (D.C. Cir. 1948); Margeson v. Boston \& M.R.R., I6 F.R.D. 200 (D. Mass. 1954).

${ }^{12}$ Accord, Crowe v. Chesapeake \& O. Ry., 29 F.R.D. 148 (E.D. Mich. 1961); United Air Lines, Inc. v. United States, 186 F. Supp. 824 (D. Del. 1960); Connecticut Mut. Life Ins. Co. v. Shields, I7 F.R.D. 273 (S.D.N.Y. 1955).

${ }^{12}$ See 2 A Barron \& Holtzoff, Federal Practice \& Procedure \& 796, at 424 (rev. ed. I961) [hereinafter cited as BARRoN \& HoLtzoff]; 4 MOORE 134.08 , at 2454. 
effort had or could successfully have been made to obtain this information by some other means. Accordingly, courts usually find "good cause" for the production of business records and accident reports, recognizing that these documents usually contain exclusive, technical information indispensable to basic issues in the case and irreplaceable by independent effort. ${ }^{13}$

Conflicting attitudes toward the scope of rule 34 exist, however, as to the production of witness statements. ${ }^{14}$ The Supreme Court in Hickman v. Taylor ${ }^{15}$ brought this conflict to the surface by denying the production of witness statements taken by an attorney in the course of his trial preparation on the ground that the moving party failed to show any "necessity" for the opposing attorney's "work product."16 Most courts of appeals have extended this "necessity" test to nonwork-product statements, ${ }^{17}$ apparently on the theory that the underlying policy choice in Hickman, to protect the privacy of the attorney's files and to preserve an efficient adversary system, also applied to these non-work-product statements. ${ }^{18}$

${ }^{13}$ Business records: See, e.g,, Bell v. Commercial Ins. Co., 280 F.2d 514 (3d Cir. 1960); Roebling v. Anderson, 257 F.2d 615 (D.C. Cir. 1958); Roth v. Bird, 239 F.2d 257 (5th Cir. 1956); Gulf Constr. Co. v. St. Joe Paper Co., 24 F.R.D. 4 II (S.D. Tex. 1959); Houdry Process Corp. v. Commonwealth Oil Ref. Co., 24 F.R.D. 58 (S.D.N.Y. 1959).

Accident reports and photographs: See, e.g., Marks v. Gas Serv. Co., I68 F. Supp. 487 (W.D. Mo. 1958); Supine v. Compagnie Nationale Air France, 21 F.R.D. 42 (E.D.N.Y. [1957]); United States v. Great No. Ry., I 8 F.R.D. 357 (N.D. Cal. I955); Aetna Life Ins. Co. v. Little Rock Basket Co., 14 F.R.D. $3_{3}$ (E.D. Ark. 1953).

${ }^{14}$ Compare Crowe v. Chesapeake \& O. Ry., 29 F.R.D. 148 (E.D. Mich. 1961)' and De Bruce v. Pennsylvania R.R., 6 F.R.D. $40_{3}$ (E.D. Pa. 1947), with Alltmont v. United States, I77 F.2d 97 I (3d Cir. 1949), cert. denied, 339 U.S. 967 (1950) and Margeson v. Boston \& M.R.R., I6 F.R.D. 200 (D. Mass, I954). See Kaufman, Judicial Control Over Discovery, 28 F.R.D. III, II5-16, I25 (196I); Taine, supra note 8, at 1027. See generally Frank, CouRTs on TrIal 93-94 (1949); Tolman, Discovery Under the Federal Rules: Production of Documents and the Work Product of the Lawyer, 58 Colum. L. REv. 498 (1958); Annot., 73 A.L.R.2d 12 (1960). ${ }^{16} 329$ U.S. 495 (1947).

${ }^{10} \mathrm{Id}$. at 508-09. For a discussion of the differing views on the "work product" doctrine, see Developments, supra note 5, at 1027-33. See also McCormick, EviDENCE $\$$ IOO (1954).

Although Hickman became the starting point for a "far-reaching [liberalizing] adjustment process concerning the attitude of the courts with respect to discovery ....," Taiue, supra note 8, at 1035 , the case can still be correctly labeled as a "veritable Pandora's Box!" Viront v. Wheeling \& L.E.Ry., Io F.R.D. 45, 47 (N.D. Ohio 1950). See generally, 4 MOORE $T 26.23$ [8].

"27 See 2 A BARRon \& Holtzoff § 796, at 419; 4 MOORE I 26.23[8], at II32.

${ }^{18}$ See, e.g., Alltmont v. United States, 177 F.2d 971, 976 (3d Cir. 1949) cert. 
Some courts, on the other hand, have tried to resist the extension of the Hickman doctrine, contending that a less stringent test of "good cause" should suffice when a non-work-product statement is desired..$^{10}$ Statements taken by claim agents, for example, have been viewed as more similar to business records, compiled in the "ordinary course of business," than to lawyers' pre-trial preparations. ${ }^{20}$ Since there is no invasion of an attorney's personal impressions, the controlling policy has been to facilitate pre-trial disclosure, minimize unfair surprise, and to promote expeditious settlement. ${ }^{21}$ Accordingly, such witness statements taken near the time of the accident have been regarded as unique and irreplaceable by deposition. ${ }^{22}$ Since the purpose of inspection is

denied, 339 U.S. 967 (1950); Wilson v. David, 21 F.R.D. 217,220 (W.D. Mich. 1957). One commentator has said this extension is in accord with the Hickman rationale, because non-lawyers and experts also perform "vital functions in litigation"; a showing of necessity to inspect their work should also be required. Taine, supra note 8, at 1051-52. Accordingly, whether the statements were made in anticipation of or in preparation for litigation would be more important than the occupation of the investigator. See Comment, 36 IND. L.J. 186, 190 (1961).

${ }^{10}$ See, e.g., Atlantic Greyhound Corp. v. Lauritzen, 182 F.2d 540, 542 (6th Cir. 1950); Scourtes v. Fred W. Albrecht Grocery Co., 15 F.R.D. 55, 58 (N.D. Ohio 1953). That something less than a showing of necessity is required when one seeks the impressions of witnesses can be supported by language in Hickman. See Hickman v. Taylor, 329 U.S. 495, 511-12 (1947). The Hickman case has been factually distinguished and found inapplicable to non-lawyer situntions where discovery would otherwise be restricted. 4 MOORE $\llbracket 26.23[8]$, at 11 32-136.

A later Supreme Court case, United States v. Procter \& Gamble, 356 U.S. 677 (1958), which denied the use of grand jury material in a civil antitrust suit, provided clues as to the scope of Hickman as then interpreted. Writing for the majority, Mr. Justice Douglas said, "[T] ogether with pre-trial procedures [discovery] makes a trial less a game of blindman's buff and more a fair contest with the basic issues and facts disclosed to the fullest practicable extent .... Only strong public policies weigh against disclosure. They were present in Hickman ... for there the information sought was in the trial notes of the opposing lawyer. They are present here because the policy of secrecy of grand jury proceedings." Id. at 682-83.

${ }^{20}$ See, e.g., Henderson v. Southern Ry., 17 F.R.D. 349 (E.D. Tenn. 1955); Panclla v. Baltimore \& O.R.R., 14 F.R.D. 196 (N.D. Ohio 195 I); Newell v. Capital Transit Co., 7 F.R.D. 732 (D.D.C. 1948); Morrone v. Southern Pac. Co., 7 F.R.D. 214 (S.D. Cal. 1947). See generally MCCorMICK, EvideNCE § 78, at 161 (2954).

"1 A court may be guided by the question of whether "the beneficial objectives of pre-trial discovery will be achieved." Crowe v. Chesapeake \& O. Ry., 29 F.R.D. 148, I5 I (E.D. Mich. 196I). A court may also follow Judge Kaufman's suggestion that discovery be permitted of all relevant information, "consonant with fairness, economy and expedition." Kaufman, supra note 14, at 115.

${ }^{22}$ See, e.g., Parla v. Matson Nav. Co., 28 F.R.D. 348,349 (S.D.N.Y. 1968); United Air Lines, Inc. v. United States, I 86 F. Supp. 824, 826 (D. Del. 1960); Brown v. New York, N.H. \& H.R.R., I7 F.R.D. 324, 325 (S.D.N.Y. 1955); Brauner v. 
either to establish a groundwork for impeachment ${ }^{23}$ or to find leads to admissible evidence, those courts favoring disclosure have also recognized that first-impression, factual observations are often more revealing and useful than statements taken at some later time, when memory has dimmed or been distorted by "outside influences."

Following this liberal approach, the trial court in Guilford attached no crucial significance to the failure of the plaintiff's attorney to make an independent effort. Rather, the court pointed out that depositions taken at the time of the motion would give no assurance that the same version of the accident was available to both parties. ${ }^{25}$ The Fourth Circuit, however, took the view that "substantial" duplication by deposition was probably still possible. ${ }^{26}$ The lack of independent effort by plaintiff's attorney was therefore significant.

In denying discovery in Guilford, the Court of Appeals was basically concerned with the dangers of unbridled discovery under rule 34. It therefore de-emphasized the special problems involved in duplicating first-impression statements of witnesses who are employees of the opposing party. District courts, on the other hand, have generally been more sensitive to the employee-witness problem. ${ }^{27}$ Some have gone so far as to presume hostility or incomplete, guarded answers. ${ }^{28}$ Other courts have recognized that the employer's control

United States, Io F.R.D. 468, 47 I (E.D. Pa. 1950), rev'd on other grounds sub nom. United States v. Reynolds, 345 U.S. I (1953).

${ }^{23}$ This purpose is a legitimate discovery objective, 4 MOORE I 34.10, at $2460-61$.

${ }^{24}$ See, e.g., California v. United States, 27 F.R.D. 261, 262 (N.D. Cal. 1961); Herbst v. Chicago, R.I. \& Pac. R.R., 10 F.R.D. 14, 18 (S.D. Iowa 1950); McCorMick, EVIDENCE $§ 34$, at 64 n.12, $\$ 39$, at 75 (1954).

26 24 F.R.D. at 499 . Accord, Pennsylvania R.R. v. Julian, ro F.R.D. 452,453 (D. Del. 1950).

${ }^{20} 297$ F.2d at 927 . This view could have been based on the premise that the substance of later statements would be just as revealing and useful as the earlier statements. See Hudalla v. Chicago, M. St. P. \& P.R.R., ro F.R.D. 363 (D. Mim. 1950); but see note 25 supra. This view could also bave been based on the idea that the preservation of the adversary system had a higher priority than furnishing the best available information. See McSparren v. Bethlehem-Cuba Iron Mines Co., 26 F.R.D. 619, 62I (E.D. Pa. 1960); Helverson v. J. J. Newberry Co., 16 F.R.D. 330, 335 (W.D. Mo. 1954); Speck, The Use of Discovery in United States District Courts, 60 YALE L.J. 1132, 1155 (1951).

${ }^{37}$ See, e.g., Sachse v. W. T. Grant Co., 27 F.R.D. 392 (D. Conn. 1961); Brown v. New York, N.H. \& H.R.R., 17 F.R.D. 324 (S.D.N.Y. 1955); Brookshire v. Pennsylvania R.R., 14 F.R.D. 154 (N.D. Ohio 1953).

${ }^{28}$ Crowe v. Chesapeake \& O. Ry., 29 F.R.D. 148, 149, 151 (E.D. Mich. 1961) (impliedly accepting moving party's contention that experience warrants assumption that train crew will be antagonistic and guarded in statements); Henderson $v$. 
over the taking of the initial statements often precludes an equal opportunity to duplicate them at a later time. ${ }^{29}$ Thus, in these cases, an absence of independent effort has been no bar to discovery under rule 34. However, many courts, including the Court of Appeals in the Guilford case, still require some specific showing of hostility or unavailability. In these forums a showing of some diligent, but unproductive effort has been a prerequisite to inspection. ${ }^{30}$

Although a primary function of appellate review is to establish the legal boundaries within which a trial judge must exercise his power, an aim of the federal discovery rules is to maximize trial judge discretion..$^{31}$ If an appellate court recognizes this goal, it will, by exercising self-restraint, reduce the scope of its own policy-making power and thereby increase that of the trial court. ${ }^{22}$ Consequently, the trial court

Southern Ry., 17 F.R.D. 349, 352 (E.D. Tenn. 1955) (safe to say parties would not remember); Herbst v. Chicago, R.I. \& Pac. R. R., xo F.R.D. I4, is (S.D. Iowa 1950) (memories of witnesses necessarily dimmed with reference to specific details).

${ }^{29}$ See, e.g., California v. United States, 27 F.R.D. 261, 262 (N.D. Cal. 1961); Cairns v. Chicago Express, Inc., 25 F.R.D. I6g (N.D. Ohio 1960); Henderson v. Southern Ry., supra note 28; Bennett v. New York Cent. R.R., 9 F.R.D. 17 (W.D.N.Y. 1949). Compare United Air Lines, Inc. v. United States, 26 F.R.D. 213 , 2 I\$ (D. Del. I960) (equal opportunity to view wreckage); United States v. Great No. Ry., 8 F.R.D. 357 (N.D. Cal. 1955) (had ample opportunity to take photos of own right of way); Scourtes v. Fred. W. Albrecht Grocery Co., I5 F.R.D. 55 (N.D. Ohio 1953) (plaintiff represented by counsel before desired statements taken); Lester v. Isbrandtsen Co., Io F.R.D. 338 (S.D. Tex. 1950) (labor union member has equal if not greater access to union member witnesses than insurance company).

${ }^{80}$ According to the Court of Appeals in Guilford, the plaintiff was in no position "to say that the employees were reluctant to speak freely ... or were openly hostile...." simce its representative had not actually spoken with them. 297 F.2d at 926 . Accord, McSparren v. Bethlehem-Cuba Iron Mines Co., 26 F.R.D. 619 (E.D. Pa. 1960); Richards v. Maine Cent. R.R., 21 F.R.D. 593 (D. Me. 1957); Tandy \& Allen Constr. Co. v. Peerless Casualty Co., 20 F.R.D. 223 (S.D.N.Y. 1957); Thompson v. Hoitsma, I9 F.R.D. 112 (D.N.J. 1956); Grogan v. Pennsylvania R.R., I I F.R.D. 342 (W.D.N.Y. I95I).

${ }^{31}$ See $2 A$ Barron \& Holmzoff $\S 803$, at 471-72; 4 MOORE T $26.23[8]$, at $1 \times 33$. As to the effect of over-active appellate review on the public's confidence in trial court action, see Wright, The Doubtful Omniscience of Appellate Courts, 4 I MiNN. L. REv. $75 x, 779-8$ I (1957).

- 39 This self-restaint is illustrated by a refusal to upset a trial judge's discretion unless the opposing party's rights have been "substantially and improvidently affected." See, e.g., Bell v. Swift \& Co., 283 F.2d 407 (5th Cir. I960); Roebling v. Anderson, 257 F.2d 6I5 (D.C. Cir. I958); Carter v. Baltimore \& O.R.R., 152 F.2d 129 (D.C. Cir. 1945 ).

On the other hand, the Guilford Court of Appeals found that the trial court had "exceeded permissible bounds" in granting the production order, even though, in almost the same breath, it recognized that the "primary responsibility for the administration of Rule 34 is upon the trial judge." 297 F.2d at $925-26$. 
would be allowed to determine whether an independent effort to obtain one's own information is necessarily required in every instance. Moreover, the trial court is in a better position to decide whether there has been an adequate or equal opportunity to gather the most reliable and useful evidence, because it is more familiar with the employee-witness problem in both the pre-trial and trial setting. Thus it can more accurately weigh the interests served by disclosure against the interests served by suppression. ${ }^{33}$

In considering the circumstances under which the plaintiff's attorney was retained in Guilford, ${ }^{34}$ the Court of Appeals seemed too impressed by the attorney's foregone opportunity to obtain written witness statements shortly after the accident." Since the value of even "substantially" duplicated statements made a year after the accident is questionable, the practical effect of the decision is to penalize the plaintiff for its lawyer's failure to obtain written statements at an earlier time. True, an attorney's unjustified procrastination should be discouraged. ${ }^{36}$

${ }^{83}$ For situations comparable to Guilford in which the moving party was also deprived of its own eyewitness to the accident, see Crowe v. Chesapeake \& O. Ry., 29 F.R.D. 148 (E.D. Mich. 1961); Brookshire v. Pennsylvania R.R., 14 F.R.D. 154 (N.D. Ohio 1953); Hesch v. Erie R.R., 14 F.R.D. 518 (N.D. Ohio 1952).

In Bifferato v. States Marine Corp., I I F.R.D. 44 (S.D.N.Y. 195 I), Judge Weinfeld recognized that he might be rewarding non-diligence by granting discovery, but felt that the denial of the motion would unduly penalize the moving party, who was impoverished and had been given trial preference. See Frost, supra note 9, at 97 .

"Three days after the accident, the attorneys were called by a friend of the decedent's family. The following day the attorneys were informed that appointed administrator, the Guilford National Bank, intended to appoint another firm to represent the estate. The next day, however, after several conferences, it was agreed that the attorneys first selected by the family friend would represent the estate as to the damage claim against the Southern Railway. Within the next four days the attorneys inspected the wrecked car, surveyed the accident scene and spoke to residents in the area and police. The tentative retainer was not officially confirmed until two weeks later. Brief for Appellant, pp. A12-14.

se The Guilford decision did not have to pass directly on this question since the witnesses were apparently still available. If, however, they were no longer available, a different and more difficult question would have been presented.

As to how some courts have treated present unavailability of witnesses, compare Cairns v. Chicago Express, Inc., 25 F.R.D. 169 (N.D. Ohio 1960) and Bifferato v. States Marine Corp., II F.R.D. 44 (S.D.N.Y. I95I) (no bar to discovery), with Grogan v. Pennsylvania R.R., 1 I F.R.D. 342 (W.D.N.Y. I95 I) and Lester v. Isbrandtsen Co., to F.R.D. 338 (S.D. Tex. 1950) and Berger v. Central Vermont Ry., 8 F.R.D. 419 (D. Mass. 1948) (discovery denied).

${ }^{80}$ It has been suggested that if the failure to make an independent effort is to be discouraged or punished, when the future unavailability of factual material was reasonably foreseeable at an earlier time, some penalty other than non-discovery should be imposed. 'Taxing attorney's fees to the party or to his lawyer through rules $3 \circ$ (b) or 
It is the trial court, however, that is in a better position to determine whether the attorney has been acting negligently or in bad faith. ${ }^{37}$ If the trial court finds that diligence would have been of little useful value, it will neither reward nor encourage procrastination by allowing discovery, and hence no damage to the adversary system would result. ${ }^{38}$

In considering the scope of rule 34, most courts of appeals have concluded that the dangers of liberal discovery and the gains from a general rule which promotes independent effort outweigh the extra expenditures of time and money that this effort necessarily entails. The Fourth Circuit has now adopted this policy choice. No doubt decisions such as Guilford encourage a party to take written witness statements whenever he has the opportunity. ${ }^{39}$ This position also

37(a) of the Federal Rules of Civil Procedure is one possibility. Developments, supra note 5 , at 1035-36.

${ }^{87}$ As to the judicial treatment of negligence, see United States v. Great No. Ry., 18 F.R.D. 357 (N.D. Cal. 1955). As to the effect of good and bad faith, compare Houdry Process Corp. v. Commonwealth Oil Ref. Co., 24 F.R.D. 58 (S.D.N.Y. 1959) and Thomas v. Pennsylvania R.R., 7 F.R.D. 610 (E.D.N.Y. 1947) (good faith), with McCaffrey v. United States, 13 F.R.D. 512 (S.D.N.Y. 1952) and Goldbloss v. Reimann, 55 F. Supp. 811 (S.D.N.Y. 1943) (bad faith).

For the use of other sanction devices, see 4 MOORE I 30.15, at 2041; Kaufman, supra note 14 , at 121 ; Wright, sucpra note 31 , at $781-82$.

${ }^{88}$ See Developments, supra note 5 , at $1029,1035$.

${ }^{29}$ If both parties are able to interview an equally co-operative witness at about the same time, they are both likely to obtain the same factual quality of information. The usual situation, however, is that one party has had a time and access advantage over the other, who may still take depositions, but who will no doubt still try, as a tactical objective, to discover the earlier statements taken by his adversary. In some cases this independent effort has paid off, as it indicates to a court that inspection is the only effective way in which the moving party can adequately prepare his case. E.g., Mitchell v. Bass, 252 F.2d 513 (8th Cir. 1958); Sachse v. W. T. Grant Co., 27 F.R.D. 392 (D. Conn. 1961); Marks v. Gas Serv. Co., 168 F. Supp. 487 (W.D. Mo. r958); Roach v. Boston Tow Boat Co., Ig F.R.D. 267 (D. Mass. 1956); Tannenbaum v. Walker, I 6 F.R.D. 570 (E.D. Pa. 1954).

On the other hand, the effort may preclude inspection if the court finds that the information has been now supplied, e.g., Hickman v. Taylor, 329 U.S. 495, 509 (1947); McSparren v. Bethlehem-Cuba Iron Mines Co., 26 F.R.D. 619 (E.D. Pa. 1960); Helverson v. J. J. Newberry Co., I6 F.R.D. 330 (W.D. Mo. 1954); MCCaffrey v. United States, ${ }_{3}$ F.R.D. 512 (S.D.N.Y. 1952), or that there is no need to go beyond depositions and interrogatories unless special circumstances are present, e.g., Endte v. Hermes Export Corp., 20 F.R.D. 162 (S.D.N.Y. 1957); United States v. Great No. Ry., 18 F.R.D. 357 (N.D. Cal. 1955). But see United States v. National Steel Corp., 26 F.R.D. 603 (S.D. Tex. 1960) (discovery remedies are cumulative, not alternative). Inconsistencies between statements may also fail to sway the court. E.g., Hauger v. Chicago, R.I. \& P.R.R., 216 F.2d 501 (7th Cir. 1954). A court can examine the depositions to see whether the testimony was in fact guarded and evasive 
avoids a potential danger that "accident-prone" industries such as common carriers would institute "selective," fact-omitting investigation techniques designed to keep prejudicial information from falling into the hands of a suing party on a mere showing of "relevancy." thermore, such decisions facilitate a uniform administration of rule 34 , as they give trial judges a standard for determining "good cause."

The major thrust of the Guilford decision is to promote diligent, independent effort, on the assumption that it will produce information as useful as the desired statements in Southern's possession. It is questionable, however, whether the Guilford circumstances warranted this assumption and hence the belief that independent effort would have been productive. A more acceptable decision, consistent with the aim of the federal discovery rules to maximize pre-trial disclosure, could have been reached if the Fourth Circuit had upheld the contempt order. The court could have rejected the "relevancy will suffice" standard, while still recognizing that "special circumstances" had been sufficiently shown without any specific evidence of a frustrated, independent effort. By adopting this modified "special circumstances" test, the court would have given prospective notice to litigants that "special circumstances" in some form, to be determined primarily by the trial judge, would henceforth be required in the Fourth Circuit.

as the moving party contends. Watn v. Pennsylvania R.R., 19 F.R.D. 358 (E.D. Pa. 1956).

The only clue Guilford gives on this dilemma is that the circumstances would have to indicate a "distinct and irremediable disadvantage to a party who is compelled to rely on statements obtained by him later than those obtained by the other party . ..." before inspection would apparently be considered. 297 F.2d at 926 . Therefore, there is no certainty in the Fourth Circuit as to whether independent effort of some sort will definitely open the door to actual inspection, unless actual resistance is encountered.

${ }^{10}$ See Frost, supra note 9, at 95; Developments, supra note 5, at 1029 .

A similar danger, involving statements taken by a lawyer himself, was recognized in the Hickman case. 329 U.S. 495, 51 I (1947).

The 1954 proposal to delete "good cause" from rule 34 , when applied to copies of non-work product witness statements was also subject to similar criticism. Due to difficulties of seemingly internal inconsistencies and the criticism of Professor Moore, this proposal was rejected. See Symposium-Federal Rules of Civil Procedure, 5I Nw. U.L. REv. 338,392 (1956).

Some courts, however, have expressly rejected the self-protective fears and defenses of "watered investigations" and have asserted that the courts, not a litigant, must determine the propriety of disclosure. See United Air Lines, Inc. v. United States, 186 F. Supp. 824, 828 (D. Del. 1960); De Bruce v. Pennsylvania R.R., 6 F.R.D. 403,406 (E.D. Pa. 1947 ). 